Gut, 1982, 23, 662-665

\title{
HLA type of patients with coeliac disease and malignancy in the west of Ireland
}

\author{
B R C O'DRISCOLL, F M STEVENS, T A O'GORMAN, P FINNEGAN, \\ J J McWEENEY, M P G LITTLE, C E CONNOLLY, and C F McCARTHY
}

From the Departments of Medicine and Pathology and Medical Research Council of Ireland Coeliac Unit, University College and Regional Hospital, Galway, Ireland

SUMmARY HLA, A, B, and DR typing was done on seven of 10 patients with lymphoma, and six patients with carcinoma, all of whom had a flat small intestinal mucosa. Sixty-nine per cent (nine of 13) had HLA B8 and 71\% (five of seven) had DR3. The corresponding levels for the local coeliac population are $76 \%$ and $84 \%$ respectively and the local non-coeliac population $43 \%$ and $44 \%$. Two of the patients with lymphoma had a child with coeliac disease. The histological type of the lymphoma was malignant histiocytosis of the intestine in seven, histiocytic lymphoma in two, and was not classifiable in one. The similarity of the HLA type suggests that the flat mucosa in both groups is due to coeliac disease.

During a 12 year period from mid 1969 to 198116 patients with malignant disease and a flat intestinal mucosa consistent with coeliac disease were seen in Galway, an area with a high prevalence of coeliac disease. ${ }^{1}$ This provided the opportunity to HLA type most of these patients and to compare the typing with that of the local population and local coeliac patients. ${ }^{2} 3$

Whether coeliac patients who develop lymphoma and other types of malignancy are similar to coeliacs who do not develop malignancy is a matter of debate. It has been suggested that the flat mucosa of some of the patients is not due to coeliac disease but might result from a long-standing lymphoma. If the genetic background, as judged by HLA typing of the patients who develop malignancy, is similar to that of coeliacs without malignancy from the same ethnic background, this would favour the suggestion that malignancy develops as a complication of coeliac disease. Similarly, the occurrence of individuals with a flat mucosa and malignancy in families of patients with coeliac disease would favour this theory.

Recently, there has been renewed interest in the histological type of lymphoma seen in these patients and this is described in our patients. ${ }^{4}$

Received for publication 7 December 1981

\section{Methods}

HLA A and B typing was done by the standard microlymphocytotoxicity test ${ }^{5}$ with sera supplied by the NIH. HLA-DR typing was done by the long B-cell enriched microlymphocytotoxicity test ${ }^{6}$ with sera supplied by Professor E D Albert (Munich).

The classification used in the histological typing of the lymphoma was modified from Robb, Smith, and

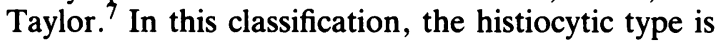
subdivided into malignant histiocytosis and histiocytic lymphoma (reticulum cell sarcoma). In the former, there is widespread dissemination of malignant histiocytes often showing erythrophagocytosis or other phagocytic activity. In the latter a tumour mass is present with or without metastases.

\section{PATIENTS}

All patients had a flat jejunal mucosa and the type of malignancy was confirmed histologically at biopsy or necropsy. The initial presenting symptoms and signs are not described as they are similar to those in other series. $^{8-11}$

\section{Patients with lymphoma}

Eight had been on a gluten-free diet for two to 25 years, one for six months, and one for a few days. Two of those on a gluten-free diet for longer than six months showed no improvement. The others 
improved clinically with weight gain of greater than $6 \mathrm{~kg}$. Three of these were on corticosteroids.

In eight patients the intestinal mucosa was studied a second time either by biopsy or at necropsy. In three who were adhering to a strict gluten-free diet there was improvement and one of five who, although on a gluten-free diet, were not adhering to it strictly also improved. Splenic weight was available in eight patients: in four the spleen weighed $30 \mathrm{~g}$ or less. The other spleens weighed $120 \mathrm{~g}, 410 \mathrm{~g}$, and $250 \mathrm{~g}$.

With one exception the patients died within a few months of diagnosis. The surviving patient (no. 6) is a 50 year old woman and she is well four years after resection of a tumour causing a jejunocolic fistula and chemotherapy. Her intestinal mucosa is almost normal.

\section{Patients with carcinoma}

One patient had been on a gluten-free diet for six years, four of the others for six months to two years. Four of the six showed clinical improvement on a gluten-free diet. In the two biopsied for a second time, the intestinal mucosa was almost entirely normal. In patient no. 13* the carcinoma of the vulva was diagnosed nine years before coeliac disease was diagnosed. This patient is alive and well 17 years after diagnosis. The other patients died within a year of diagnosis of malignancy. Spleen weight was available in one patient - it was $160 \mathrm{~g}$.

* Patient no. 13 died recently from an undifferentiated carcinoma of the mid-oesophagus.

\section{Results}

HLA type is included in the Table. Two of the patients had children with coeliac disease. An 8 year old son of patient no. 6 had a jejunal biopsy done because his mother thought he was not as well as his siblings. The mucosa was flat and after a year on a gluten-free diet had become almost normal. His HLA type was A1, B8, B18, DR3, DR2. A 29 year old daughter of patient no. 7 had a jejunal biopsy done because of long-standing diarrhoea. The mucosa was flat. She gained $12 \mathrm{~kg}$ on a gluten-free diet. The biopsy has not been repeated. Her HLA type was A1, A2, B8, B14.

\section{Discussion}

An indisputable diagnosis of coeliac disease requires the demonstration of abnormal small intestinal mucosa, which improves when gluten is excluded from the diet and deteriorates when gluten is reintroduced. In practice, and in particular in adults, it is unusual to require more than the demonstration of significant mucosal abnormality and its improvement on a gluten-free diet. As patients with malignancy and a flat intestinal mucosa frequently die shortly after the diagnosis of malignancy, there is often no opportunity to assess the effect of a gluten-free diet. In some patients the clinical course even with a gluten-free diet is of steady deterioration without morphological improvement in the intestinal mucosa, and malignancy, usually

Table HLA and tumour type of patients with coeliac disease and malignancy

\begin{tabular}{|c|c|c|c|c|c|c|}
\hline & $\operatorname{Sex}$ & $\begin{array}{l}\text { Age* } \\
(y r)\end{array}$ & Tumour type & HLA type & & \\
\hline 1 & $\mathbf{M}$ & 26 & MHI + & \multicolumn{3}{|c|}{$\mathrm{A} 1, \mathrm{~A} 10, \mathrm{~B} 8, \mathrm{~B} 18$} \\
\hline 2 & M & 59 & MHI & & & \\
\hline 3 & $\mathrm{~F}$ & 48 & MHI & & & \\
\hline 4 & $\mathbf{F}$ & 47 & MHI & & & \\
\hline 5 & M & 58 & MHI & A2, A9, & B7, B14 & DR1, DR4 \\
\hline 6 & $\mathbf{F}$ & 50 & HL $†$, jejunum & $\mathrm{A} 1, \mathrm{~A} 19$ & $\mathrm{~B} 8, \mathrm{~B} 12$ & DR3, DR7 \\
\hline 7 & $\mathbf{F}$ & 57 & HL, stomach & Al, A11, & $\mathrm{B} 8, \mathrm{~B} 12$ & DR3 \\
\hline 8 & $\mathbf{M}$ & 67 & MHI & $\mathrm{A} 1, \mathrm{~A} 19$ & B5 & \\
\hline 9 & $\mathbf{F}$ & 64 & MHI & $\mathrm{A} 1$ & B8 & DR3, DR4 \\
\hline 10 & $\mathbf{M}$ & 67 & Lymphomat & $\mathrm{A} 1$ & B8 & DR6, DR7 \\
\hline 11 & $\mathbf{F}$ & 68 & Adenocarcinoma $\ddagger$, pancreas, & & & \\
\hline & & & or duodenum & $\mathrm{A} 1, \mathrm{~A} 3$, & B15 & \\
\hline 12 & $\mathbf{M}$ & 50 & Adenocarcinoma, pancreas & A2, A19, & B8 & \\
\hline 13 & $\mathbf{F}$ & 43 & Carcinoma, vulva & $\mathrm{A} 1, \mathrm{~A} 19$ & $\mathrm{~B} 8, \mathrm{~B} 12$ & \\
\hline 14 & $\mathbf{F}$ & 53 & Adenocarcinoma, jejunum & A9, A19, & B7, B8 & \\
\hline 15 & M & 70 & Squamous cell, lung & $\mathrm{A} 1, \mathrm{~A} 3$ & $\mathrm{~B} 8, \mathrm{~B} 14$ & DR3 \\
\hline 16 & $\mathbf{M}$ & 50 & Adenocarcinoma & A1, & $\mathrm{B} 8, \mathrm{~B} 12$ & DR3 \\
\hline
\end{tabular}

* At diagnosis of malignancy.

† MHI: malignant histiocytosis of intestine. HL: histiocytic lymphoma. Lymphoma: unclassifiable.

¥ Surgeon could not determine origin of tumour at laparotomy. 
lymphoma, being dignosed at necropsy.

In the absence of demonstrable mucosal improvement in some of these patients the diagnosis of coeliac disease could be disputed. Nevertheless, there was no evidence that other disorders associated with a flat mucosa were present. The effect of gluten exclusion from the diet could not be ascertained in some because of the short duration of history before death.

The HLA type of the coeliacs and non-coeliacs in the local population has been detailed previously. ${ }^{23}$ Seventy-six per cent of the local coeliacs have HLA B8 and $84 \%$ DR3. This is a similar proportion to most other coeliac populations ${ }^{12} 13$ with the exception of Southern Germany. ${ }^{14}$ In the noncoeliac population the comparable figures are $43 \%$ and $44 \%$. The incidence of HLA B8 and DR3 in the non-coeliac population in the Galway area is higher than elsewhere.

Nine $(69 \%)$ of the 13 patients with malignancy in whom HLA typing was done had HLA B8 and five of seven had DR3. Information on HLA type in a series of patients with lymphoma or carcinoma and coeliac disease against a background of HLA type in a local population of coeliacs is not available in the literature. The similarity of the proportion of HLA B8 and DR3 in the malignant and non-malignant coeliac groups suggest that the two groups share similar genetic backgrounds and we believe that both groups are coeliacs. This opinion is supported by the presence of coeliac disease in two of the children of patients with lymphoma. Why some coeliacs develop malignancy and others do not is as obscure as the reasons why lymphoma or other malignancies develop in the general population. Abnormal absorption of environmental carcinogens or undue penetration of the abnormal jejunal mucosa by oncogenic viruses in the presence of disturbed immunity are speculative possibilities.

Although we believe that the lymphomas and at least some of the carcinomas arise in relationship to coeliac disease, we cannot exclude a primary relationship to HLA B8, although we are not aware of such an association of HLA B8 with malignancy.

In many of these patients the almost simultaneous diagnosis of coeliac disease and malignancy suggests that the latter was the event that drew attention to the underlying partially or totally asymptomatic coeliac disease.

During the period these patients were seen (1969 to 1981) 21 patients with coeliac disease died in this area. This number includes 14 of the 16 patients mentioned in this study. The proportion of deaths due to malignancy $(67 \%)$ is somewhat higher than in other studies. Holmes et al ${ }^{9}$ reported 21 of 43 deaths due to malignancy and 13 of the tumours were lymphomas. Whorwell et al ${ }^{15}$ found 31 of 77 deaths to be due to malignancy and 10 of these were due to lymphoma.

During the years in which these patients developed malignancy, 198 patients with coeliac disease presented after the age of 12 years. From 1956 to 1981,252 patients were diagnosed in the Paediatric Department and none of these has developed malignancy (personal communication, Professor B McNicholl). The proportion of adult coeliacs who have developed malignancy so far is $8.08 \%$ (16 of 198$)$ and is similar to the $11.8 \%$ reported by Selby $e t a l^{11}$ and the $7 \%$ due to lymphoma reported from Sweden. ${ }^{16}$

The histological appearances of the lymphoma in this series indicate that a histiocytic tumour is the type that develops in coeliac patients in this area and supports the views of Issacson and Wright ${ }^{4}$ that malignant histiocytosis of the intestine is the type usually found in coeliac disease.

We thank our collegues who referred patients to us, who assisted in their investigation and treatment, and those who provided details of patients who were under their care at sometime. We are grateful for HLA sera supplied by the National Institutes of Health, Bethesda, Maryland, and by Professor E Albert of Munich. Miss M Bourke, M Kearns, and $\mathrm{R}$ McKenna, $\mathrm{PhD}$ did the HLA typing. Dr $\mathrm{P}$ Issacson's discussion of the histopathology of some of the tumours was most helpful to us. The Medical Research Council of Ireland provided generous financial assistance.

\section{References}

1 Mylotte MJ, Egan-Mitchell B, McCarthy CF, McNicholl B. Incidence of coeliac disease in the West of Ireland. Br Med J 1973; 1: 703.

2 Stevens FM, Egan-Mitchell B, Watt DW, Baker SH, McNicholl B, McCarthy CF. HLA antigens in coeliac disease and a control population in the West of Ireland. In: McNicholl B, McCarthy CF, Fottrell PF, eds. Perspectives in coeliac disease. Proceedings of 3rd International Coeliac Symposium 1977. Lancaster: MTP, 137-44.

3 McKenna R, Stevens FM, Bourke M, McNicholl B, Albert ED, McCarthy CF. B-cell alloantigens associated with coeliac disease in the West of Ireland. In: McConnell RB, ed. The genetics of coeliac disease. Proceedings of International Symposium on the Genetics of Coeliac Disease 1979. Lancaster: MTP, 153-9.

4 Isaacson $\mathrm{P}$, Wright $\mathrm{DH}$. Intestinal lymphoma associated with malabsorption. Lancet 1978; 1: 67-70.

5 Terasaki PI, McClelland JD. Microdroplet assay of 
human serum cytotoxins. Nature 1964; 204: 998-1000.

6 Van Rood JJ, Van Leeuween A, Keuning JJ, Busse Van Oud A. The serological recognition of the human MLC determinants using a modified cytotoxicity technique. Tissue Antigens 1975; 5: 73-9.

7 Robb-Smith AHT, Taylor CR. Lymph node biopsy. A diagnostic atlas. London: Miller Heyden, 1981: 262.

8 Harris OD, Cooke WT, Thompson H, Waterhouse JAH. Malignancy in adult coeliac disease and idiopathic steatorrhoea. Am J Med 1973; 1: 899-911.

9 Holmes GKT, Stokes PL, Sorahan TM, Prior P, Waterhouse JAH, Cooke WT. Coeliac disease, gluten free diet and malignancy. Gut 1976; 17: 612-9.

10 Freeman HJ, Weinstein WM, Shnitka FK, Piercey JRA, Wensel RH. Primary abdominal lymphoma. Am $J$ Med 1973; 63: 585-94.

11 Selby WS, Gallagher ND. Malignancy in a 19 year experience of adult coeliac disease. Dig Dis Sci 1979; 24: 684-8.
12 Falchuk ZM, Rogentine GN, Strober W. Predominance of histocompatibility antigen HLA-A8 in patients with gluten sensitive enteropathy. J Clin Invest 1972; 51: 1602-5.

13 Stokes PL, Holmes GKT, Asquith P, Mackintosh P. Histocompatibility antigens associated with adult coeliac disease. Lancet 1972; 162-4.

14 Harms K, Granditsch G, Rossipal E, et al. HLA patients with coeliac disease and their families. In: Hekkeno WThJM, Pena AS, eds. Coeliac disease. Proceedings of 2nd International Coeliac Symposium 1974. Leiden: Stenfert Kroese, 215-77.

15 Whorwell PJ, Foster KJ, Alderson MR, Wright R. Death from ischaemic heart disease and malignancy in adult patients with coeliac disease. Lancet 1976; 11: 113-5.

16 Brandt L, Hageander B, Norden A, Stenstam M. Lymphoma of the small intestine in adult coeliac disease. Acta Med Scand 1978; 204: 467-70. 